\title{
ОМОГРАФИЧЕСКИЕ ТРИАДЫ В РУССКОМ ЯЗЫКЕ
}

\author{
HOMOGRAPHIC TRIADS IN RUSSIAN
}

\author{
JERZY KALISZAN
}

\begin{abstract}
The article is devoted to the study of Russian homographic rows consisting of three components, such as ворона (gen. and acc. sg. of ворон 'raven') - ворона (nоm. sg.) 'crow' - Ворона (short form of вороной 'black'), вертела (gen. sg. of вертел 'spit for roasting') - вертела (nom. and acc. pl. of вертел) - вертела (past of вертеть 'to turn'), здорово (adv.) 'greatly, superbly; hard, strongly' - здорово (short neut. form of здоровый I 'healthy') - здорово (short neut. form of здоровыи II 'tremendous, hefty'). The author has analyzed and classified 70 such three-component groups of homographs revealed in contemporary Russian.
\end{abstract}

Jerzy Kaliszan, Uniwersytet im. Adama Mickiewicza w Poznaniu, Poznań - Polska, kaliszan@amu.edu.pl

В работах, посвященных русской омографии, которых, кстати, пока еще очень немного, объектом анализа избираются почти исключительно двойные (бинарные) оппозиции одинаковых по написанию, но не омофоничных - ввиду акцентных различий - словоформ одной и той же лексемы или двух отдельных лексем, напр.: волос - волос, реки - реки, большая - большая, носите (индикатив) - носите (императив) или замок 'крепость' - замок 'механизм', потом (твор. ед. к пот) - потом (нареч.), окуни (им. мн. к окунь) - окуни (императив к окунуть). В данной статье речь пойдет о тройных омографических оппозициях, которые в современном русском языке не являются редкостью и к тому же характеризуются рядом особенностей, заслуживающих подробного анализа и обстоятельного описания на исчерпывающем фактографическом материалеㄹ.

Трехчленные ряды одинаковых по написанию, но акцентно дифференцированных словесных знаков могут создаваться, естественно, только за счет единиц, состоящих по крайней мере из трех слогов, ср.:

${ }^{1}$ Аналитический материал был почерпнут нами из различных типов словарей современного русского языка - толковых, орфографических, орфоэпических, грамматических, словарей омонимов, омографов и некоторых других лексикографических источников. 
сторожа (род. $/^{*}$ вин. ед. к сторож) - сторожа (им. ед.) устар. 'сторожевой пункт, застава' - сторожа (им. мн. к сторож); сторожа (род. / вин. ед. к сторож) - сторожа (им. ед.) - сторожа (дееприч. к сторожить); выводим (буд. вр. к выводить) - выводим (наст. вр. к выводить) - выводим (кратк. ф. прил. выводимый). С другой стороны, однако, длина слов, участвующих в образовании омографических триад, не превышает уровня четырех слогов, ср.: перепела (род. / вин. ед. к перепел 'птица') - перепела (им. мн. к перепел) - перепела (прош. вр. к перепеть); выводите (буд. вр. / императив к выводить) - выводите (наст. вр. к выводить) - выводите (императив к выводить).

Тройные омографические ряды можно разделить на несколько типов, учитывая их лексемный и частеречный состав, а также характер структурно-семантических отношений между их компонентами. Так, компоненты отдельных рядов могут быть словоформами двух или трех разных лексем, они могут репрезентировать одну, две или три части речи, они, наконец, могут отличаться друг от друга по лексическому и / или грамматическому значению. На этой основе целесообразно говорить соответственно о двулексемных и трехлексемных омографических триадах, о внутричастеречных и межчастеречных триадах и, наконец, о триадах, составленных из лексико-грамматических омографов и омографов смешанного типа.

Так, с точки зрения числа лексем, репрезентируемых компонентами триад, доминирующими оказываются двулексемные триады, составляющие приблизительно $61,5 \%$ собранного нами аналитического материала. Их компонентами являются формы двух разных лексем, т. е. одна форма, принадлежащая какой-либо одной лексеме, и две формы, принадлежащие другой лексеме, ср.: сторожа (им. ед.) устар. 'сторожевой пункт, застава' - сторожа (род. / вин. ед. к сторож) - сторожа (им. мн. к сторож); провода (род. ед. к провод 'действие по значению глагола проводить') - провода (род. ед. к провод 'проволока') - провода (им. / вин. мн. к провод); перепела (прош. вр. к перепеть) - перепела (род. / вин. к перепел) - перепела (им. мн. к перепел); железы (им. / вин.; плюратив, устар. 'оковы, кандалы') - железы (род. ед. к железа) - железы (им. / вин. мн. к железа) и многие другие.

* Здесь и далее косая черта „/" сигнализирует, что в случае омоформии, т. е. грамматической омонимии форм одной и той же лексемы, компонентом конкретного омографического ряда может, естественно, выступать только одна из омонимичных форм, вторая же или остальные омонимичные формы входят в состав другого или других омографических рядов. Так, запись сторожа (род. / вин. ед.) - сторожа (им. ед.) - сторожа (им. мн.) вмещает в себя два омографических ряда: сторожа (род. ед.) - сторожа (им. ед.) - сторожа (им. мн.) и сторожа (вин. ед.) - сторожа (им. ед.) - сторожа (им. мн.). 
Трехлексемные триады, т.е. триады, формируемые словоформами трех разных лексем, встречаются реже, чем двулексемные, и составляют около $38,5 \%$ всего аналитического материала. Это такие ряды омографов, как: волоку (дат. ед. к волок 'участок суши между двумя судоходными реками') - волоку (вин. ед. к Волока техн. 'рабочий инструмент волочильного стана') - Волоку (1 л. ед. к Волочь); Ворона (род. / вин. ед. к Ворон) - Ворона (им. ед.) - ворона (кратк. ф. ж. р. прил. Вороной); воронъю (твор. ед. к Воронъ 'чернь, наведенная на металл') - Воронью (дат. к Воронъё - собир. 'стадо ворон или воронов') - Воронью (вин. ед., ж. р. к Вороний); сторожа (род. / вин. ед.) - сторожа (им. ед.) устар. 'сторожевой пункт, застава' - сторожа (дееприч. к сторожить); выносим (буд. вр. к выносить) - выносим (наст. вр. к Выносить) - выносим (кратк. ф. прил. выносимый); ужиная (дееприч. к ужинать) - ужиная (дееприч. к ужинать обл. 'сжинать, срезать серпом - о хлебных злаках') - ужиная (им. ед., ж. р. к ужиныи - от уж 'рептилия'); здоpobo I (нареч.) 'хорошо, удачно, искусно; очень, сильно' - здорово I (кратк. ф. прил. здоровый I 'не больной') - здорово (кратк. ф. прил. здоровый II 'значительный по размерам или степени проявления'); здорово I (нареч.) - здорово II (нареч.) 'выражая здоровье или свидетельствуя о нем' - здорово (кратк. ф. прил. здоровый II); здорово II (предикатив) 'оценка чего-л. как вызывающего восхищение, доставляющего удовлетворение, удовольствие' - здорово III (межд.) 'здравствуй(те)!' - здорово (кратк. ф. прил. здоровый II).

Деление омографических троек на двулексемные и трехлексемные плотно сопряжено с делением их на внутричастеречные и межчастеречные омографы.

В составе внутричастеречных рядов отдельные их компоненты, относясь к одной и той же части речи, репрезентируют две лексемы, одна из которых в трехчленном омографическом ряду представлена двумя грамматическими формами. Таким образом, внутричастеречная омография является последовательно двулексемной. Она представлена в языке субстантивными или глагольными триадами. К первым относятся такие, между прочим, оппозиции, как: железы (им. / вин. мн. к железа) - железы (род. ед. к железа) - железы (им. / вин.; плюратив, устар. 'цепи, оковы'); округа (род. ед. к округ) - округа (им. / вин. мн. к округ) - округа (им. ед.) 'окружающая местность; окрестность'; отруба (род. ед. к отруб 'участок земли') - отруба (им. / вин. мн. к отруб) - отруба (род. ед. к отруб 'место разруба'); подреза (род. ед. к подрез 'часть полоза саней') - подреза (им. / вин. мн. к подрез) - подреза (род. ед. к подрез 'действие по значению глагола подрезать'); nривода (род. ед. к привод - в проф. речи 'техническое приспособление') - привода (им. / вин. мн. к привод) - привода (род. ед. к привод юрид. 
'принудительное доставление лица в суд'); провода (род. ед. к провод 'проволока') - провода (им. / вин. мн. к провод) - провода (род. ед. к провод 'действие по значению глагола проводить'); пролога (род. ед. к пролог 'церковная книга') - пролога (им. / вин. мн. к пролог) - пролога (род. ед. к пролог 'вступление'); сторожа (род. / вин. ед. к сторож 'лицо') - сторожа (им. мн. к сторож) - сторожа (им. ед.) устар. 'сторожевой пункт, застава' и под. К глагольным внутричастеречным триадам принадлежат такие, например, оппозиции, как выводите (буд. вр. / императив к выводить) - выводите (наст. вр. к выводить) - выводите (императив к выводить); вывозите (буд. вр. / императив к вывозить разг. 'выпачкать, вымазать, вывалять') - вывозите (наст. вр. к вывозить) - вывозите (императив к вывозить); выносите (буд. вр. / императив к выносить) - выносите (наст. вр. к выносить) - выносите (императив к выносить); выходите (буд. вр. / императив к выходить 'вырастить, воспитать') - выходите (наст. вр. к выходить) - выходите (императив к выходить). К глагольным внутричастеречным можно отнести и триады, составленные из двух предикативных глагольных форм и одной атрибутивной (причастной): выводим (буд. вр. к выводить) - выводим (наст. вр. к выводить) - выводим (кратк. ф. прич. выводимый - от выводить); вывозим (буд. вр. к вывозить разг. 'выпачкать, вымазать, вывалять') - вывозим (наст. вр. к Вывозить) - вывозим (кратк. ф. прич. вывозимый - от вывозить); выносим (буд. вр. к выносить) - выносим (наст. вр. к выносить) - выносим (кратк. ф. прич. Выносимый - от выносить).

Межчастеречная тройная омография покрывает около $47 \%$ аналитического материала, минимально уступая первенство внутричастеречной (53\%). Она бывает либо двулексемной, либо трехлексемной и создается соответственно взаимоотношением формы одной лексемы и двух форм другой лексемы, отличной от первой в частеречном плане, или взаимоотношением форм трех отдельных лексем, две из которых относятся к одной и той же части речи. Первый случай иллюстрируют субстантивно-глагольные ряды типа Вертела (род. ед. к вертел 'металлический прут, на котором жарят мясо, птицу и т. п., поворачивая его над огнем') - вертела (им. / вин. мн. к Вертел) - вертела (прош. вр. к Вертеть); перепела (род. / вин. ед. к перепел) - перепела (им. мн. к перепел) - перепела (прош. вр. к перепеть); слесаря (род. / вин. ед. к слесарь) - слесаря (разг. ф. им. мн. к слесарь) - слесаря (дееприч. к слесарить разг. 'заниматься слесарной работой, быть слесарем')2; токаря (род. / вин. ед. к токарь) - токаря (разг. ф. им. мн. к токарь) - токаря (дееприч. к токарить разг. 'заниматься токарной

2 Деепричастия, как и причастия, вслед за академической Русской грамматикой (Русская грамматика, под ред. Н.Ю. Шведовой, т. 1, „Наука”, Москва 1980, с. 664-674), трактуются здесь как формы глагола, а не как отдельные части речи. 
работой, быть токарем'). Второй случай можно продемонстрировать, во-первых, субстантивно-глагольными триадами, напр.: волоки (им. / вин. мн. к Волок 'участок суши между двумя судоходными реками') - волоки (род. ед. / им. / вин. мн. к волока техн. 'рабочий инструмент волочильного стана') - волоки (императив к волочь); волоку (дат. ед. к волок) - волоку (вин. ед. к Волока) - волоку (1 л. ед. к Волочъ); сторожа (род. / вин. ед. к сторож) - сторожа (им. ед.) 'сторожевой пункт, застава' - сторожа (дееприч. к сторожить); сторожу (дат. ед. к сторож) - сторожу (вин. ед. к сторожа) - сторожу (1 л. ед. к сторожить); во-вторых, субстантивно-адъективными триадами типа ворона (род. / вин. ед. к Ворон) - ворона (им. ед.) - ворона (кратк. ф. ж. р. прил. вороной); воронью (твор. ед. к Воронь 'чернь, наведенная на металл') - воронью (дат. к Воронъё - собир. 'стадо ворон или воронов') - воронъю (вин. ед., ж. р. к Вороний); или, в-третьих, глагольно-адъективными триадами вроде выводим (буд. вр. к выводить) - выводим (наст. вр. к выводить) - выводим (кратк. ф. прил. выводимый); выносим (буд. вр. к выносить) - выносим (наст. вр. к выносить) - выносим (кратк. ф. прил. Выносимый); ужиная (дееприч. к ужинать 'есть вечером, съедать ужин') - ужиная (дееприч. к ужинать обл. 'сжинать, срезать серпом - о хлебных злаках') - ужиная (им. ед., ж. р. к ужиный - от уж 'рептилия').

Омографические тройки, как указывалось выше, можно дифференцировать и по характеру соотношения лексического и грамматического значения их компонентов. Для этого могут быть отчасти использованы типологические критерии, применяемые обычно при изучении бинарных омографических оппозиций ${ }^{3}$ Так, члены тройных омографических рядов могут быть лексико-грамматическими омографами, т. е. иметь разные лексические и разные грамматические значения, напр.: выносим (буд. вр. к выносить) - выносим (наст. вр. к Выносить) - выносим (кратк. ф. прил. Выносимый); ворона (род. / вин. ед. к Ворон) - ворона (им. ед.) - Ворона (кратк. форма ж. р. прил. вороной); Воронью (твор. ед. к Воронъ 'чернь, наведенная на металл') - воронъю (дат. к Воронъё - собир. 'стадо ворон или воронов') - Воронью (вин. ед., ж. р. к воронии); волоку (дат. ед. к волок 'участок суши между двумя

${ }^{3}$ В связи с этим см.: Н.П. К о л е с н и к о в, Система словесных омонимов в русском языке, [в:] ХІІ научная сессия филологического факультета. План работы и тезисы докладов, Тбилиси 1968; А.И. М е л ь н и к о в а, К вопросу о русских омографах, „Русский язык в школе" 1974, № 4; ее же, Пути возникновения и развития омографии в русском языке, „Русский язык в школе” 1988, № 4; М.И. Ф о м и н а, Современный русский язык. Лексикология, „Высшая школа”, Москва 1978, с. 62-63; М.Г. П е т р е н к о, Явление омографии в современном русском языке. Автореф. дисс. ...канд. филол. наук, Одесса 1987; О.Н. Е м е л ь я н о в а, Омонимия и смежные явления, [в:] Стилистический энциклопедический словарь русского языка, под ред. М.Н. Кожиной, „Флинта: Наука", Москва 2003, с. 263-267. 
судоходными реками') - волоку (вин. ед. к Волока техн. 'рабочий инструмент волочильного стана') - волоку (1 л. ед. к Волочъ); здорово (нареч.) 'хорошо, удачно, искусно; очень, сильно' - здорово (предикатив) 'полезно для здоровья' - здорово (кратк. ф. прил. здоровый 'значительный по размерам или степени проявления'). Лексико-грамматические омографы последовательно относятся к межчастеречной омографии. Они одновременно являются компонентами трехлексемных омографических рядов.

Лексико-грамматическому типу следует противопоставить смешанный семантический тип, при котором любой из компонентов омографической триады отличается от каждого из двух остальных компонентов либо по лексическому, либо по грамматическому, либо же одновременно и по лексическому и по грамматическому значению, напр.: округа (род. ед. к округ) - округа (им. / вин. Мн. к округ) - округа (им. ед.) 'окружающая местность; окрестность'; отруба (род. ед. к отруб 'участок земли') - отруба (им. / вин. мн. к отруб) - отруба (род. ед. к отруб 'место разруба'); выводим (буд. вр. к выводить) - выводим (наст. вр. к выводить) - выводим (кратк. ф. прич. к выводить); выносите (наст. вр. / императив к выносить) - выносите (наст. вр. к Выносить) - выносите (императив к выносить); Вертела (род. ед. к Вертел) - вертела (им. / вин. мн. к Вертел) - Вертела (прош. вр. к Вертеть); сторожа (род. / вин. ед. к сторож) - сторожа (им. мн. к сторож) - сторожа (им. ед.) 'сторожевой пункт, застава'; настригу (дат. ед. к настриг 'количество настриженной шерсти, получаемое при стрижке овец') - настригу (дат. ед. к настриг 'настригание') - настригу (буд. вр. к настричъ); ужиная (дееприч. к ужинать 'есть вечером, съедать ужин') - ужиная (дееприч. к ужинать обл. 'сжинать, срезать серпом') - ужиная (к ужиный - прил. от уж 'рептилия'). Смешанный тип омографии конституируют как внутри-, так и, значительно реже, межчастеречные омографы. Триады смешанного типа являются преимущественно триадами двулексемного, реже трехлексемного типа. Они составляют $75,7 \%$ всего аналитического материала, втрое перекрывая число лексико-грамматических омографов.

Среди трехсторонних омографических оппозиций по лексической и грамматической семантике нам не удалось установить наличия в современном русском языке ни одного случая лексической омографии, т. е. наличия тройных омографов, обладающих разным лексическим значением и одинаковым грамматическим значением. Среди тройных омографов нет и, естественно, не может быть и грамматических омографов, т. е. акцентных оппозиций форм одной и той же лексемы, так как в русском языке не существует слов с тремя омографичными друг другу словоформами. 
Итак, выше были выделены и описаны основные, на наш взгляд, типы омографических триад, характерных для современного русского языка. Как видно из примеров, эти типы могут взаимно пересекаться, перекрещиваться. Строительным материалом, наполняющим отмеченные нами тройные омографические ряды отдельных типов, являются, по данным нашей картотеки, формы 65 лексем, в том числе 32 субстантивов, 7 адъективов, 21 глагола, 2 наречий, 2 предикативов (слов категории состояния, стативов) и 1 междометия. Различные комбинации этих форм дают 70 тройных омографических оппозиций различных типов. Правда, число этих оппозиций не идет ни в какое сравнение с насчитывающими десятки тысяч омографическими диадами, но зато тройные ряды графически идентичных, но фонетически и семантически противопоставленных друг другу словесных знаков являют собой весьма интересный и до сих пор особо не отмеченный в литературе эксклюзивный пример неоднозначности в языке и, по нашему мнению, уже хотя бы поэтому абсолютно не могут обходиться молчанием в лингвистических описаниях. Потребность в их изучении диктуется и тем, что они составляют часть, пусть и незначительную, весьма обширной и чрезвычайно сложной омографической картины русского языка, выделяющей этот язык на фоне других европейских языков. Детальное исследование этой картины может, кроме теоретической пользы, принести и весомую практическую помощь и оказаться ценной для тех, кто изучает русский язык как иностранный.

\section{Библиография}

Е м е ль я н о в а О.Н., Омонимия и смежные явления, [в:] Стилистический энциклопедический словарь русского языка, под ред. М.Н. Кожиной, „Флинта: Наука”, Москва 2003.

К о л е с н и к о в Н.П., Система словесных омонимов в русском языке, [в:] ХІІ научная сессия филологического факультета. План работы и тезисы докладов, Тбилиси 1968.

М е л ь н и к о в а А.И., К вопросу о русских омографах, „Русский язык в школе” 1974, № 4.

М е л ь н и к о в а А.И., Пути возникновения и развития омографии в русском языке. „Русский язык в школе” 1988, № 4.

П е т р е н к о М.Г., ЯВление омографии в современном русском языке. Автореф. дисс. ...канд. филол. наук, Одесса 1987.

Русская грамматика, под ред. Н.Ю. Шведовой, т. 1, „Наука”, Москва 1980.

Ф о м и н а М. И., Современный русский язык. Лексикология, „Высшая школа”, Москва 1978. 
